\title{
Harmony communication in peace language and conflict resolution
}

\author{
Fajar Dwi Putra ${ }^{\mathrm{a},{ }^{, *},}$, Sebastian Smolak ${ }^{\mathrm{b}, 2}$ \\ ${ }^{a}$ University of Ahmad Dahlan, Jl. Kapas No.9, Semaki, Kec. Umbulharjo, Kota Yogyakarta, Daerah Istimewa Yogyakarta 55166, Indonesia

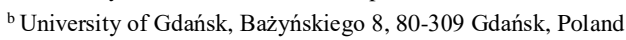 \\ ${ }^{1}$ fajar.dwipa@comm.uad.ac.id, ${ }^{2}$ sebastian.smolak@wp.pl \\ * corresponding author
}

ARTICLE INFO

Article history

Received 2020-06-05

Revised 2020-06-17

Accepted 2020-07-01

Keywords

Harmonization

Communication

Conflict Resolution

\section{ABSTRACT}

This study aims to provide an overview of language and conflict resolution to achieve communication harmony. Certain types of description was used to obtain the data more apparently because of related to phenomena and analysis of cases in the community. The conclusions of this study are communication harmony consists of language and communication. Communication becomes very important in giving a touch of the peace symbol. Communities must join together, deliberately creating collective space, starting with oneself, family, and the lowest social level. Although the harmony of communication has not yet materialized, we need to give the maximum extra gratitude for the language of peace from ourselves to the highest level.

This is an open access article under the CC-BY-SA license.

\section{Introduction}

Prejudice for the sake of prejudice is scattered in several phases of life, and the fact is that the world is already filled with prolonged conflict that makes people suffer. Harmony is a method of surviving or building lost trust. That is, harmony occurs to create opportunities for warmth that have vanished in society's eyes. The world is destroyed because of communication; the world can be peaceful also because of communication. In communication, there is something called language. The function of language is not only as a symbol of civilization, more than that, language as a trail of time to continue to communicate with time.

However, in a more complex field, peace theory alone is not enough to diagnose conflict and all the elements that help it. In addition to the general theoretical foundation, humans and society need effective models and tools to achieve an accurate and useful diagnosis. I use the terms "theory" and "model" in specific and different ways, and this brings me to the key question: What is the difference between "theory" and "model"? Usually, the terms "theory" and "model" are used almost interchangeably, and indeed there is overlap in their meanings. Theory on simple implications is a kind of analysis knife to divide dimensions and fear of opinion. With the theory, the road is wide open, and some foreign walls are collapsed cannot be built again. The analysis is a dewdrop that soothes the mind and hopes about a thing in the future.

While the model is an example of the results of the analysis of theory, for example, peace is a model, in the model, some forms and consequences must be borne. The form of a peace model is 
comfort in life, freedom of thought, not attacking each other. Theoretical analysis is needed to know how to make a model so that the opportunity to gain sharpness of thought becomes very broad.

These definitions show that theories are broad principles that are often associated with higherorder abstract thought. Theories are closely related to research by testing hypotheses or principles to see if they are correct. In scientific methods, if a theory is not verified or cannot be proven right, it will be discarded as a mistake or not used. This scientific approach is found in many professions (including social science and conflict resolution). In a science, "pure" or "theoretical" is a term used to research that initially gives little or no thought to practical uses or applications. Instead of focusing on unraveling the basic principles with little regard for whether it is "practical," "There is much money spent, and many people are involved in this type of research in many fields, including conflict resolution, the language of peace.

Apart from the research component in most fields, there are also "practices" or applied branches of the field centered around "practitioners," who take existing field knowledge and determine how to apply it to help reduce world tensions directly. The term "theory," therefore, seems to direct us toward abstract inquiry with fewer applications. This is why many professions describe a significant separation in their fields between research and practice, between theoretical work and the social application of that knowledge in the social sphere and conflict.

Strategic culturalist analysis to create a peace language that seriously recognizes culture needs to consider at least three levels: public culture, strategic culture, and military culture. Moreover, these cultures will not always be harmonious. On the trail left behind the urgency of the language of peace, the philosophy of peace has been buried in the people's time and stories. It is not only related to society's story; even some people consider this a myth that haunts in conflicting countries.

From the social system that should be maintained as well as possible, there is a new order resulting from division, which is a matter of justice. This becomes very relevant when the main topic of this discussion is about the language of peace. How fair is the world to humans? Thoughts and activities outside the home? Do they feel safe with such conditions, or peace, peace of mind is only an illusion or a gateway to dreams?

The question of fairness can be very relevant to strategic performance. At the very least, these questions reduce the need to recognize the occasional tension between fighting well in an ethical sense and fighting effectively in the pursuit of economic victory. Geography relevant to the conflict has evolved this century from land and sea level to encompass airspace and space and the electromagnetic spectrum (EMS), including the current primacy of cyberspace.

There is always a geographical dimension to the conflict. Geography is the same as history and culture; it is one dimension that can be treated so inclusive that it begins to dominate theory, analysis, and explanation. Almost unchanged even though in physical geography, the meaning can change with technology. The significance of the need for a peace language does not change only with technology because technology cannot be treated separately as a determinant of strategic history. The terrain of conflict, climate of division, and certain distances about humanity on the world geography map, for example, can be reduced significantly in principle.

The language of peace that comes from around the world is imprisoned for various reasons and purposes. The tension of a conflict will not bring any positive impact. Instead, it will damage the world order and its devices. As the front guard in placing peace positions, humans must provide a real understanding of the low literacy and high culture of self-winning. Peace does not require a large group; it only needs trust and responsibility to look after it.

\section{Theoritical Framework}

This research is based on several theoretical foundations to provide a broader view. Harmony is derived from harmonics, which means the first harmonic, basic tuning, or fundamental components or harmony [1]. If supported, the meaning of the word harmony contains social meaning, happiness, and links with the actual form on the broader community. So, if combined, Communication Harmony is harmony in communicating or communicating with the aim of peace and peace. Peace is security, security, justice, and peace [2], while conflict resolution is part of all our lives or nonviolent functions [2]. Society has two elements. First, it is relational: it consists of relationships that 
influence each other, between agents, and between agents and material objects that also form the social environment. The Second Element is the community that also has a level of depth behind what appears on the surface and the surface level that has a special meaning. This explanation shows the social world formed from two different types, namely society, and agents [3].

This analytical viewpoint is based on understanding logical atomism, which means that understanding which holds language can be broken down into atomic parts or division of elements through logical analysis techniques or language analysis. Each proposition is in an agreed-upon part of reality [4]. The rationality of action is an act of putting on a summary that leads to a reference/norm, and ways available to provide a direct reference in terms of action [5] or a social modification that is sometimes incompatible with its substance [6].

\section{Method}

This research used a particular case study method, a research approach to provide an overview of a particular situation, event, program, or phenomenon. Simultaneously, this type of research leads to descriptive, that provides a systematic, factual, and accurate description of the facts and characteristics of the population or specific objects.

\section{Results and Discussion}

Conflicts based on historical identity, religious beliefs, language, or symbolic areas are very difficult to compromise on fundamental questions such as God's oneness. For example, whether a holy area can belong to one group or other groups (for example, the conflict between Hindus and Muslims in India over the Ayodhya Mosque) [7].

Actually, it is not difficult to detect how the basic principles of structural linguistics can be applied to the ideological analysis. The difference between language and parable is to give two movable environments to express two levels of each speech or system and signs as the language of peace, namely, the contents of real and latent or hidden language. The real content is in the form of speech, while the latent content illustrates the conversation structure that forms the basis. It can be presumed that this latent structure is equivalent to ideology. That is, ideology arranges a kind of structure hidden in each of the talks delivered and received wrapped in an external and opaque form [8].

If we use the analysis of logical atomism, a reference will be very useful when broken down into several points of view to find problems in language. Solving sentences and language positively affects the logic system of society. The existence of sentences and language refers to the word "there" for every phenomenon in the world. In the study of word philosophy, one understanding is found that says, "I speak, then I am" and "there is no enlightenment without anxiety and doubt" [9].

This shows that every word must have an end or enlightenment. Every phenomenon of disunity, the hostility that occurs because of words and language, will end well, even though the time span is different. Conflicts are manifested through social actions of hostility, which involve two or more actors with expressions of difference that are often accompanied by intense hostilities [10]. We take an example of conflict in the Middle East that is still burning. The conflict began with border issues, embargoes as a form of protest between nations, racial and religious conflicts. The language of the media used is "border" and not restriction. Then the phrase "border" is interpreted as a limitation, which means deliberately carried out restrictions.

The rationality of social action on conflict is influenced by the logical limits of every human being in viewing and interpreting a language of peace. Because the difference between right and wrong is made by a group of people based on their will, that difference occurs from bargaining people in a particular environment. Then, fostering a sense of obligation and guilt from the sentiment of the process of various things [11] to read the situation in some conflicts requires a technique called prudentia or words and situations. The author quotes prudent from Aristotle's view of the ability to determine what is right and what is bad [12]

That ability is not owned or understood by the public and conflict makers so that the situation that occurs is disunity. The second trigger for conflict is the media or the press. The press is behind a split. This is due to two factors. The first, news or news content factors, and the second is the factor 
of community responsibility in receiving and understanding news content. News content is referred to as the mainstream to spread understanding and information, containing persuasive language and sentences. I am trying to study a social responsibility theory that must be possessed by the media and the wider community.

The emergence of social responsibility theory is known as the libertarian theory. Theoretically, social responsibility theory is seen as a way out for the libertarian theory. This theory says every human being is a rational creature and can achieve its own goals. So that the state does not need to interfere in all matters of society, including the press [13], this understanding means that humans are free to want. Social freedom is arbitrary so what happens is brutality in managing information. Global destruction can occur due to the refraction of each language's meaning, even though the language in the press media aims to provide peace for each country and people. The use of the language of euphemism and hyperbole that often appears in the press is disguising the truth of the revealed context. The press's language should have clarity, accuracy, communicative, and obedient to the meaning finally distorted. Next comes the vague language (ambiguous and multi-meaning), which can lead to unclear meaning.

The problem of euphemism and hyperbole in the press's language occurs when maps of cultural thought are developed, and the concept of national personality is implemented through the language of the press. What happened was a clash about the concept of identity as an applicative form of the hegemony system's ability. So that the concept of perfect culture would become the realm of euphemism and hyperbole; thus, it becomes unclear between the descriptions arranged by words and reality. Because with the support of power, metaphorical words turn into reality representations. As a result, we are lulled by forms of imagination that are separated from reality [14]

any people or institutions are too rushed to see conflict. Many institutions and universities that conduct peace studies conduct war studies to calculate violent conflicts carefully, analyze them, and sometimes see how they end up with a truce [15], which is one of the parameters of world violence. One does not see the form of peace, but behind it, the parameters are violence and civil war.

The language of peace can be meaningful. Make no mistake about war language because humans often too quickly infer a symbol, language, and communication, for example, Pigeons, a message of peace from Pigeons because of Greek mythology related to the little white bird with Aphrodite, the goddess of love. Aphrodite or Venus are often depicted with pigeons flying around or resting in their hands. Peace, conflict resolution, and language are still the world's homework to immediately provide a solution, using symbols and messages of peace, because the world is too tired to tell war and death to children and history.

Semiotics of peace can be given or made by agreement. A peace or conflict resolution has its meaning and message. The point is how to equalize the perception of the language of peace. Humans have been fighting too long, and humans need time to rest and enjoy the world's beauty without conflict. Living peacefully is the ultimate goal of humankind at the end of time. Individuals develop attitudes and ways of thinking that often result in habits or behavior patterns when dealing with conflict. Attitudes and patterns can interfere with achieving maximum negotiation effectiveness by obscuring frustrating situation evaluations and appropriate strategic choices. Before it is possible to develop effective negotiation strategies, it is necessary to diagnose conflicts appropriately. Before we can diagnose conflict quickly, we need to recognize our tendency to deal with conflict. This strategy's specialty is the nature of the conflict, circumstances, and individuals involved [16] What must we do to deal with conflict? Conflict will increase or disappear because of conflict management style. People react to what is said and done. Do defend, attack, retreat, calm. This is a dynamic moment and you control the direction and the end result with the process you use by using words and energy.

As long as you can translate you and me into us, you will develop an affinity, relationships, and cooperation. If not, there is a possibility of division, frustration, and escalation of the conflict. In conflicts, people usually feel under threat of losing something important to them. This perceived threat puts them in a defensive position, and there is little chance for collaboration while it remains. Joint solutions are more likely to be reached if threats, real or imaginary, are eliminated. [17].

Conflicts often arise as a result of tensions between different cultural perceptions and diverse social choices. [18] The underlying cause of social inequality is sublimated humanity. Through the 
language of peace, the world should be in a position of compassion. But, on the contrary, what happened was division and hostility. It seems true what was conveyed by Jean Baudrillard a modern philosopher from France who said "When domination occurs, it becomes difficult to distinguish between fact and fiction. It creates hypereality or reality created by the mass media [19].

When the foreign culture concerned tolerates, even rewards, behavior, which Western liberal democracies consider to be a brutal act, or entirely unacceptable for ethical reasons [20]. The peace refers to how the system is built by the state, society, and some supporting elements such as systems, discipline, mutual respect, and a good perception of a language's translation. War is only a continuation of political relations; in practice, the grammar of war and a peace strategy show what policies exist and what not [21].

The concept of security in world peace has long been imprisoned by conservative thinking. Exploring security as an instrumental value that allows individuals and groups to pursue human life and predetermined destiny [22]. The modern world has been damaged several times by war. Every major conflict in 1792-1815, 1914-18, 1939-45, and 1947-89 had a transformative effect on international relations. War was once available as a direct policy option. In balance, he has become a relatively stable political agent, while parents, politics, and others have served parties that contain certain historical motives [23].

The language of peace is a social institution, waged not only by the state but by society. Due to various varieties and contexts, the language of peace has anything that resembles a standard social impact. Because the language of peace is an internal reason for themselves and the context is literal, it is important for their understanding. The language of peace requires contextualization. The context is so significant that it can overwhelm scholars with the pleasing result that the language of peace is a strategic tool for creating peace throughout the world. But keep in mind, the strategic history of peace emerges in an uncertain context, sometimes not linear with what is aspired. In fact, there is a purpose of chaos behind peace which is temporary [24].

Peace seen from any perspective is an element of humanity. In fact, it can be said its presence in the midst of world-class society enters the realm of ironic skepticism, because peace is always fought but is not maintained [25], that flow is called collective space. This space is produced jointly and is the birthplace of collective actions. In this space recognizing unusual actions are considered to be common, in other words, harmony is deliberately swallowed raw by a custom of something unusual in the dynamics of peace [26]. If this continues to occur, then the language of peace will be paralyzed, the world will be increasingly destroyed just because of humans' bad collective nature.

My worries happened again. If the language of peace has faded, times have begun to show signs of time destruction. Everything will change along with the emergence of new hybrids in the arena of life. Times and eras formed pockets of efforts to save peace in their own way and in certain regions to produce new civilizations. A new era is coming; lifestyles and human behavior are changing, world organizations are coming to make the old organization fall. Humans cry out for eternal peace, while their historical traces have been buried deeply by themselves. A realization is too late to save humans from extinction [27].

This happens due to the clash of morality and social system analysis in looking at the importance of peace language. This interpretation presents one of two important elements in the deviation of social morality. The first element exists to define morality. It's not too difficult to just realize that morality is not a simple entity. The second element is social. As we know that morality is intrinsically not enough to change people's behavior, it is necessary to have a social system such as rules and great discipline because society is the most obvious enemy of actualizing roles [28].

Managing communication behavior is indeed not easy, especially human behavior throughout the world that cannot be observed in detail. Nevertheless, there is at least one language of peace that is used to unite thoughts and opinions. The Matouschka model is a model that specializes in the competitive nature of its people. This relates to the personality of the self to conduct discipline therapy or self-control [29].

Conflict situations can be very diverse, and because the model is not the only reference and exclusive representation of "truth," we are not looking for a single model that will make sense of every conflict in the world. Instead, we need to feel comfortable with various models that help us diagnose different problems and with different people. I tried to see the conflict using Mayer's "lens" 
analogy so that the initial analysis and diagnosis to obtain the word "language of peace" could be realized. For example, conflicts can be seen through communication lenses, types of conflict lenses, interest's lenses, personality lenses, structural lenses, cultural lenses, conflict lens dynamics, and more [30].

The language of peace is a meeting point between human needs in the world with cultural expectations and social systems. Conflict resolution is considered as a lighter or an element that can submerge conflict slowly. The emergence of differences in determining not the language of peace is the source of all divisions. Cause at this time, there is still much collective space; they destroy the earth more slowly from the human side. The peace that is hoped for now rests on all of us. One solution is to improve language configurations, through the mass media or the surrounding community. War is more than a true chameleon, which slightly adjusts its characteristics to the given case. As a total phenomenon, its dominant tendency always makes war an extraordinary trinity, consisting of violence, hatred, and primordial hostility. It is considered to be a huge natural force about the game of aid and hope in which zeal can be sought to explore and which is not convincing is not supported, as a policy instrument, which is agreed by reason alone.

War and war are different concepts, and differences are very important. Simple, popularly used interchangeably as a matter of literary comfort. While strategists have been known to have the same conversation with understanding, while being understood, that is less forgiven for ignorance. Every chance that rolls, then there are millions of opportunities for peace are missed. Sometimes humans contemplate putting psychological pressure on world behavior and systems created to control lust. Peace exists as a form of human responsibility towards social and fellow human beings. The end of the attitude of world peace is the high tolerance on each side. Pray, one day, the world will be calmer because humans are good at adopting the language of peace, creating harmony in communication to reduce more conflicts between people. Half, even more, the world's population currently lives in the shadow of a deadly threat, causing them to torment in their hearts and souls. Hope becomes the final dock for realizing peace, starting from the context of language and communication. Do not let the world get destroyed just because of human selfishness and want to win alone. God has given the world as a representation of God's attributes. Explaining this peace language requires a negotiating table for getting to know one another, distributing abilities to the world, and people. Things opposite bad possibilities start to think about, because at this time, and time still hangs at the end of all humans' hope. No one can predict when the earth-shaking will occur, at least if it happens, we are no longer in a state of dispute.

The right decision. As a significant stretch for the timeliness, one must then consider whether the idea is right or wrong. On the battlefield of cyberspace, electronic warfare precisely mocks geography and previous times. However, everything in the battle related to technical speed cannot be eliminated with time and time. Precisely time will be in power with each other's policies and operations, and no longer requires time spent on technical progress. In particular, time is an ally of world power, and the will and fighters are irregular in researching any conflict that is completely unusable with the swift victory. Time remains on the wall of the world until the time limit is set. However, time will also hold people to account because it is not used to reconcile the world. Why is the world currently seriously ill? The main factors that must be taken are people and systems that have no sense of respect.

Some strategies are gathered into two that are made by themselves to penetrate all conditions and conditions, and there is no room to lean on the burden and hope about peace, which is only the sound of a cannon boom and the invasion of hot lead troops. They are happy and no longer trust people. Every soul is a turbulent enemy, and there is no trust, all will lead to large-scale destruction. Humans must think about peace, use any language, anywhere and at any time because at this time the world needs transfusions and injections of warmth to restore order and better conditions.

\section{Conclusion}

In this research, we give the resolution to one or two things. The first is the minimum escalation of peace supported by war, secondly, about humans who are bad at implementing treatment systems. The assistance system is a time giving to give and give a broad effect to each environment. What we are feeling right now is happening all over the world. Many have been concerned about, and many souls are separated from the fundamentals. World viruses are being attacked by Corona, which 
directly touches the channel and requires communication. The hotter, the more out of control if we are still the same as in previous years. Peace must be made immediately. At present, peace is only premature, out of control, and enter the minds of humans, which are only temporary without regard to history traces. Humans more often play a role on the safe side, and there is no interest or resistance. All of these dangerous points become the roots and the beginning of the history of world destruction. For me, this is an extraordinary and expensive work because humans do not keep promises about God, who created the world and humans from the same side. Whenever we are confronted with a dispute, the first thing we do is try to understand it. Try to determine what the conflict is. In other words, the First Step is trying to diagnose conflict. After we decide (or guess) the cause, Step Two takes some action based directly on what we think is the main cause. The first must be to creatively and deeply diagnose what causes conflict. The second is effectively and skillfully taking action to resolve the conflict. In many cases, obstacles to managing conflict effectively are we diagnose conflicts unconsciously, react quickly and emotionally, make choices and apply tools based on low diagnoses, and ultimately improve the situation. If the diagnosis is an ability and the first key for a professional peace volunteer, it is crucial to understand how the conflict diagnostic process works and suitable volunteers. In general, most diagnoses are rooted in the background of theoretical knowledge in the field.

\section{References}

[1] P. B. D. P. Nasional, Kamus Besar Bahasa Indonesia. Jakarta: Departemen Pendidikan Nasional, 2008.

[2] E. C. M. Morton Deutsch, Peter T. Coleman, Handbook of Conflict Resolution, 1st ed. Bandung: Nusa Media, 2016.

[3] Nanda Amalia, Harmonisasi dan Konflik, 1st ed. Lhokseumawe: Unimal Press, 2013.

[4] David E. Cooper, Filsafat dan Sifat Bahasa, 1st ed. Yogyakarta: Pustaka Pelajar, 2018.

[5] William Outhwaite, The Blackwell Dictionary of Modern Social Thought, 2nd ed. 550 Swanston Street, Carlton, Victoria 3053, Australia: Blackwell Publishing, 2006.

[6] Giles Deleuze, Spinoza "Filsafat Praktis," 1st ed. Yogyakarta: basabasi, 2018.

[7] J. Pellokila, Demokrasi dan Konflik yang Mengakar: Sejumlah Pilihan untuk Negosiator, 1st ed. Depok: International IDEA, 2000.

[8] Tom Bottomore, Konsep Ideologi, 1st ed. Yogyakarta: LKPSM, 1996.

[9] Reza A. A. Wattimena, Filsafat Kata, 1st ed. Jakarta: PT Evolitera, 2011.

[10] Ho Won Jeong, Conflict Management and Resolution, 5th ed. USA and Canada: Taylor \& Francis eLibrar, 2010.

[11] Donald B. Calne, Batas Nalar, 2nd ed. Jakarta: Gramedia, 2005.

[12] Zainul Maarif, Retorika Metode Komunikasi Publik, 2nd ed. Jakarta: Rajagrafindo Persada, 2017.

[13] Salvatore Simarmata, Media dan Politik. Jakarta: Yayasan Obor Indonesia, 2014.

[14] Ismail, Ironi dan Sarkasme Bahasa Politik Media, 1st ed. Yogyakarta: Pustaka Pelajar, 2013.

[15] T. M. J. S. S. Byrne, Critical Issues in Peace and Conflict Studies, 1st ed. United Kingdom: Rowman \& Littlefield Education, 2011.

[16] Barbara A. Budjac Corvette, Conflict Management: A Practical Guide to Developing Negotiation Strategies, 1st ed. England: Printed in the United States of America, 2014.

[17] SHAY \& MARGARET Mcconnon, Conflict Management In The Workplace, 1st ed. Oxford: How To Conten, 2008.

[18] Xiaodong Dai and Guo-Ming Chen, Conflict Management and Intercultural Communication, 3rd ed. New York: Routledge, 2017.

[19] Kompas, Humanisme dan Kebebasan Pers, 1st ed. Jakarta: Penerbit Buku Kompas, 2001.

[20] Colin S. Gray, Fighting Talk, 1st ed. United States of America: British Library Cataloguing, 2007.

[21] Colin S. Gray, Modern Strategy, 1st ed. Oxford: Oxford University Press, 1999. 
[22] Ken Booth, Theory of World Security, 2nd ed. Madrid, Cape Town, Singapore, São Paulo: Cambridge University Press, 2007.

[23] Colin S. Gray, War, Peace and International Relations, 1st ed. New York: Library of Congress Cataloging in Publication, 2007.

[24] Colin S. Gray, War, Peace and International Relations an Introduction to Strategic History, 2nd ed. New York: Simultaneously published, 2007.

[25] Peter L. Berger, Humanisme Sosiologi, 1st ed. Jakarta: Inti Sarana Aksara, 1985.

[26] F. B. Hardiman, Memahami Negativitas, 1st ed. Jakarta: Penerbit Buku Kompas, 2005.

[27] Rhenald Kasali, Disruption, 9th ed. Jakarta: Penerbit Buku Kompas, 2018.

[28] George Ritzer, Sosiologi, 1st ed. Yogyakarta: Pustaka Pelajar, 2013.

[29] Prof Deddy Mulyana, Komunikasi Kontekstual, 2nd ed. Bandung: PT Remaja Rosdakarya, 2013.

[30] Gary T. Furlong, The Conflict Resolution Toolbox, 1st ed. Mississauga, Ontario: Tri-graphic Printing, 2005. 